\title{
A histological and immunohistochemical study of beta cells in streptozotocin diabetic rats treated with caffeine
}

\author{
Siham K. Abunasef ${ }^{1,2}$ Hanan A. Amin ${ }^{1,3}$, Ghada A. Abdel-Hamid ${ }^{1,4}$ \\ ${ }^{1}$ Anatomy Department, Faculty of Medicine, King Abdulaziz University, Saudi Arabia \\ ${ }^{2}$ Histology Department, Faculty of Medicine, Ain Shams University, Egypt \\ ${ }^{3}$ Histology Department, Faculty of Medicine, Cairo University, Egypt \\ ${ }^{4}$ Anatomy Department, Faculty of Medicine, Suez Canal University, Egypt
}

\begin{abstract}
In this study, the histological, immunohistochemical, morphometric, and biochemical changes to pancreatic beta-cells in STZ-induced diabetes were evaluated in rats treated with different doses of caffeine. Fifty adult male Wistar albino rats were divided into five groups: the nondiabetic control group, the diabetic untreated group, and three diabetic groups treated with different doses of caffeine (10,50, and $100 \mathrm{mg} / \mathrm{kg} / \mathrm{day})$. Blood glucose and serum insulin levels were measured. The pancreata were collected and processed into paraffin sections. They were stained using hematoxylin and eosin (H\&E) and Masson trichrome stains. The insulin expression in beta-cells was assessed using immunohistochemistry. Morphometrically, the percentage area of anti-insulin antibody reaction, the percentage of beta-cells per total islet cell number, and the average area of the islets were determined. STZ-induced degenerative changes in beta-cells led to decreases in the number of functioning beta-cells and insulin immunoreactivity and to increases in the number of collagen fibers in the islets. In STZ-treated rats, caffeine significantly decreased blood glucose concentration while increasing blood insulin levels at the highest applied dose. It also induced a significant increase in the number of immunoreactive beta-cells. In conclusion, caffeine may have a protective role in the biochemical and microscopic changes in pancreatic beta-cells in diabetes induced in rats through STZ administration. (Folia Histochemica et Cytobiologica 2014, Vol. 52, No. 1, 42-50)
\end{abstract}

Key words: streptozotocin; caffeine; diabetes; insulin; islet structure; beta cells; IHC

\section{Introduction}

Caffeine, one of the methylxanthines, is naturally found in beverages such as coffee [1]. It is probably the most widely consumed psychoactive substance, due to its presence in coffee, tea, and medicinal products [2]. The effect of caffeine on glucose tolerance is still controversial, as previous studies have indicated that blood glucose concentrations are found to be, variously, higher, lower, or unchanged following caffeine

Correspondence address: G.A. Abdel-Hamid, Assistant Professor of Anatomy Anatomy Department, Faculty of Medicine, King Abdulaziz University, Jeddah 21551, Kingdom of Saudi Arabia, P.O.Box:42806;

e-mail: ghada169@hotmail.com administration [3, 4]. Diabetes mellitus is a common chronic human disease. Experimental induction of diabetes mellitus in animal models is essential for understanding the various aspects of its pathogenesis and to suggest of new therapies [5].

Streptozotocin (STZ; N-nitro derivative of glucosamine) has been found to be a cytotoxic chemical to the pancreatic insulin-producing beta-cells of the islets of Langerhans in mammals [6, 7]. Injection of STZ results in the degeneration of beta-cells [8]. Induction of experimental diabetes in the rat using STZ has been found to be effective, convenient, and simple to use $[6,9]$. Clinically, the symptoms of diabetes have been clearly seen in rats given single dose of STZ $(60 \mathrm{mg} / \mathrm{kg})$ intravenously or intraperitoneally, within 2-4 days following injection [10]. 
Historically, caffeine has been the subject of extensive research, and studies have been conducted in various species in order to determine the impact of caffeine on various biochemical and physiological processes. Beside its psychoactive effects, it also affects the endocrine, cardiovascular, respiratory, renal, and digestive systems [11]. However, there have been few studies of organ changes on the microscopic level subsequent to the experimental induction of diabetes. The present study aimed to evaluate the idea that caffeine might have a beneficial effect on a chronic degenerative disease like diabetes. The effects of different caffeine doses on the biochemical, histological, immunohistochemical, and morphometric alterations to islets of Langerhans beta-cells was investigated, with special reference to insulin secreting beta-cells, following the experimental induction of diabetes using streptozotocin (STZ).

\section{Material and methods}

Animals and experimental procedures. Fifty adult male Wistar albino rats weighing 250-275 g were purchased and housed in the animal facility at King Fahd Medical Research Center (KFMRC), Jeddah, Saudi Arabia. The experiment was conducted in accordance with the ethical rules and guidelines of the Canadian Council on Animal Care.

The rats were maintained at $22-24^{\circ} \mathrm{C}$, with $55 \%$ relative humidity with light and dark periods at 12 -h light/12-h dark intervals, starting at 6 a.m. Animals had free access to food and water, and were acclimatized for one week before the beginning of the experiment.

The rats fasted for 18 hours prior to the induction of diabetes mellitus. Diabetes was induced by a single intraperitoneal injection of streptozotocin ( $\mathrm{N}$-(methyl nitroso carbamoyl) alpha-D-glucosamine, Sigma, St. Louis, MO, USA) at the dose of $60 \mathrm{mg} / \mathrm{kg}$ body weight [12]. Freshly made solutions of STZ dissolved in $0.1 \mathrm{M}$ citrate buffer $(\mathrm{pH} 4.5)$ were immediately prepared 10 minutes prior to injection, on account of the instability of STZ in solution. The nondiabetic control rats (group I) also received an injection of the citrate buffer. Following the injections, the rats had free access to $(5 \%)$ glucose solutions for 24 hours in order to avoid the anticipated hypoglycemic shock. 72 hours following the injection, tail blood samples from overnight fasting rats were obtained to measure blood glucose and insulin levels. Rats with blood glucose levels above $250 \mathrm{mg} / \mathrm{dL}$ were classified as diabetic animals and were selected for the caffeine treatment [13].

Study design. Fifty rats were divided into two main groups. Group I consisted of the control nondiabetic group $(\mathrm{n}=10)$, while group II consisted of the diabetic animals ( 40 rats that had been treated with STZ). Control animals were injected intraperitoneal (ip) with equivalent volumes of saline at the same time that the rats of group II received caffeine. The diabetic animals were subdivided into 4 groups $(n=10$ each). Group IIa included untreated diabetic rats: these were injected (ip) with equivalent volumes of saline. Groups IIb, IIc, and IId, the treated diabetic rats, were treated daily for 6 weeks by (ip) injections of 10, 50, and $100 \mathrm{mg} / \mathrm{kg} \mathrm{BW}$, respectively, of caffeine (Sigma) dissolved in saline [14]. The dissolved caffeine was filtered through a disposable sterile filter membrane immediately before injection.

\section{Measurements of blood glucose and serum insulin concen-} trations. Blood samples were drawn from each group 2, 4, or 6 weeks after caffeine administration. After fasting for $18 \mathrm{~h}$, a blood drop was taken from the distal end of the tail, applied to a test strip, and analyzed immediately via a blood glucose monitoring system with a blood glucose monitoring device (Accu-Check Active, Roche Diagnostics, Mannheim, Germany) [15].

By the end of the experiment but before sacrifice, the rats were anesthetized with ether, and blood samples were collected from the retro-orbital blood plexus by inserting a capillary tube in the medial canthus. Blood samples were centrifuged and their sera were stored at $-80^{\circ} \mathrm{C}$ until analysis. Insulin concentration was measured in serum $(\mu \mathrm{IU} / \mathrm{mL})$ using a rat-specific Insulin-Ak ELISA (DPC, Los Angeles, CA, USA) [16].

Histological study. The pancreata were harvested from the sacrificed rats after dissection, and were weighed and washed with saline. The specimens were stretched on filter paper and fixed in $10 \%$ buffered formalin ( $\mathrm{pH} \mathrm{7.4).} \mathrm{The}$ fixed specimens were sliced, processed, and embedded into paraffin blocks. The blocks were cut into $4 \mu \mathrm{m}$ paraffin sections by a rotator microtome. The sections were stained with Hematoxylin and Eosin (H\&E) and with Masson trichrome stains [17].

Immunohistochemical staining. Four-micrometer-thick paraffin sections were mounted on positively charged slides and subjected to the immunohistochemical (IHC) procedure using an Avidin-Biotin detection system (Ventana, Tucson, AZ, USA), following the manufacturer's instructions. Sections were incubated with polyclonal guinea pig anti-insulin antibody (1:100) (N1542, Dako, Carpinteria, CA, USA) for $10 \mathrm{~min}$ at room temperature. The IHC procedure was performed by an automatic immunostainer (Ventana Bench Mark XT, Ventana). Positive control slides (from archived blocks of previously positive pancreas) were included in each staining session. The negative control was nonimmune guinea pig serum in $0.05 \mathrm{M}$ Tri-HCL-buffer at $\mathrm{pH}$ 7.6. The reaction was visualized using 3,3-diaminobenzidine tetrahydrochloride (DAB Substrate Kit, Thermo Fischer Scientific, Rockford, IL, USA). Sections were counterstained with Harris hematoxylin. Slides were examined and photographed 
using a light microscope (BX51, Olympus, Tokyo, Japan) fitted with an Olympus digital camera (DP20) [18].

Image analysis. Morphometric measurements of the digitalized images of immunostained sections were carried out using the Image Pro plus image analyzer computer system (Media Cybernetics, Rockville, MD, USA). The following parameters were assessed:

1. Percentage area $(\%)$ of anti-insulin antibody reaction in islets was measured, in 5 islets from 5 different microscopic fields from five paraffin blocks randomly selected from each group - thus, from 5 rats from each group.

2. The percentage of beta-cells per total islet cell number was calculated by counting the number of cell nuclei as reference. The nuclei of all islet cells per islet profile were counted. The number of beta-cells $(\mathrm{Bn})$ and the total number of islet cell nuclei (In) allowed determination of the beta-cell percentage per islet cell (beta-p). The following equation was used to calculate this: beta-p $=(\mathrm{Bn} / \mathrm{In}) \times 100$. This parameter was calculated for approximately 4 islets in each specimen and for 40 islets in each group [19].

3. The average area of the islets was determined by measuring the area of 4 islets in each section of one rat, and in total for 40 islets from each group [20].

Statistical analysis. Statistical analysis was performed using SPSS statistical software, version 15.0 (SPSS Inc., Chicago, IL, USA) for Windows. Data were analyzed and presented as means $\pm \mathrm{SD}$. Differences between continuous data were analyzed using one-way ANOVA. $\mathrm{P}<0.05$ was considered significant.

\section{Results}

\section{Effect of caffeine on fasting blood glucose concentration}

Fasting blood glucose (FBG) concentration increased significantly $(\mathrm{P}<0.05)$ following STZ injection in all groups compared with the control group during the duration of the experiment. The rats in group IId, which received a dose of $100 \mathrm{mg} / \mathrm{kg}$ caffeine, showed a significant decrease $(\mathrm{P}<0.05)$ in $\mathrm{FBG}$ over the course of the experiment ( 6 weeks), as compared with the rats of the untreated diabetic group IIa (Table 1).

\section{Effect of caffeine on serum insulin concentration}

The mean serum insulin level in all the STZ-treated rats decreased significantly $(\mathrm{P}<0.05)$, as compared with the control animals. The mean blood insulin concentration of the diabetic rats that received caffeine increased with the caffeine dose. Serum insulin concentration of the diabetic rats that received caffeine at a dose of $100 \mathrm{mg} / \mathrm{kg} \mathrm{BW}$ (group IId) was significantly
Table 1. Effect of streptozotocin and caffeine on fasting blood glucose concentrations

\begin{tabular}{|l|c|c|c|}
\hline \multirow{2}{*}{$\begin{array}{l}\text { Experimental } \\
\text { groups }\end{array}$} & \multicolumn{3}{|c|}{ Period of treatment } \\
\cline { 2 - 4 } & Two weeks & Four weeks & Six weeks \\
\hline $\begin{array}{l}\text { Group I } \\
\text { control) }\end{array}$ & $70.2 \pm 2.7$ & $65.4 \pm 3.2$ & $68.4 \pm 1.5$ \\
\hline $\begin{array}{l}\text { Group IIa } \\
\text { (diabetic: STZ) }\end{array}$ & $250.5 \pm 12.4^{*}$ & $253.9 \pm 14.1^{*}$ & $257.7 \pm 1^{*}$ \\
\hline $\begin{array}{l}\text { Group IIb } \\
\text { (STZ + caffeine } \\
10 \mathrm{mg} / 100 \mathrm{~g} \mathrm{BW})\end{array}$ & $257.2 \pm 14.2^{*}$ & $256.4 \pm 14^{*}$ & $252.2 \pm 3.2^{*}$ \\
\hline $\begin{array}{l}\text { Group IIc } \\
\text { (STZ + caffeine } \\
50 \mathrm{mg} / 100 \mathrm{~g} \mathrm{BW})\end{array}$ & $235.2 \pm 17.1^{*}$ & $230.4 \pm 9.1^{*}$ & $232.2 \pm 3.7^{*}$ \\
\hline $\begin{array}{l}\text { Group IId } \\
\text { (STZ + caffeine } \\
100 \mathrm{mg} / 100 \mathrm{~g} \mathrm{BW})\end{array}$ & $166.5 \pm 18.2^{*, \#}$ & $165.5 \pm 12.2^{*, \#}$ & $164.5 \pm 18.2^{*, \#}$ \\
\hline
\end{tabular}

Blood glucose levels were determined as described in Methods and expressed as mean \pm SD.Rats were injected i.p. withstreptozotocin (STZ) at a dose $60 \mathrm{mg} / \mathrm{kg}$ BW. Then rats from groups IIb, IIc and IId were treated daily for 6 weeks by i.p.injections of caffeine at the indicated doses. ${ }^{*} \mathrm{P}<0.05$, compared to control group (group I); ${ }^{\#} \mathrm{P}<0.05$, compared to diabetic group (group IIa).

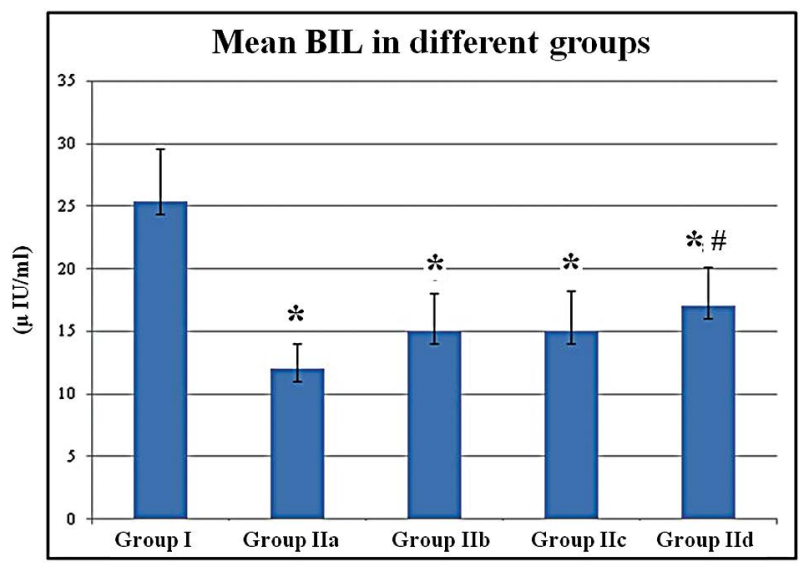

Figure 1. Mean blood insulin levels (BIL) in different groups. "Significantly different from Group I (nondiabetic control), $\mathrm{P}<0.05$; ${ }^{\#}$ Significantly different from Group IIa (diabetic), $\mathrm{P}<0.05$

higher than in the diabetic rats of group IIa that did not receive caffeine (Figure 1).

\section{Morphology of pancreatic islets}

Examination of H\&E stained sections from the control group showed the pancreas to have a normal histological structure. The islets of Langerhans appeared as noncapsulated pale stained rounded or oval areas inside the pancreatic lobules, which were formed of groups of 

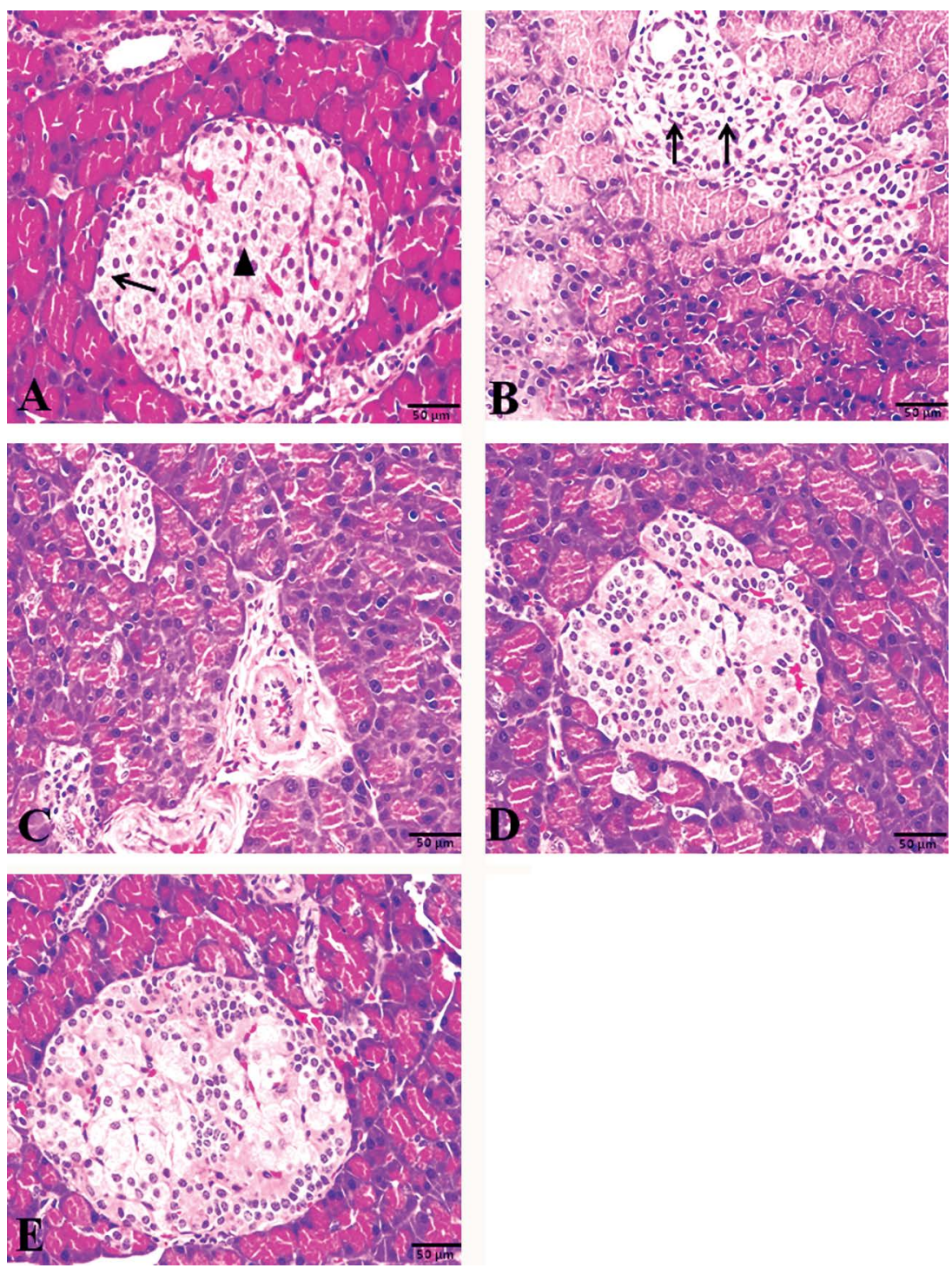

Figure 2. Photomicrographs of sections of the pancreas stained by H\&E. A. Section from control group showing granulated cytoplasm of islet cells with small, dark nuclei on the periphery (alpha-cells) (arrow), or with light and large nuclei (beta-cells) (arrowhead); B. Section from pancreas of a diabetic rat (group IIa) showing cytoplasmic degenerative changes in most islet cells, especially in center of the islet. Notice the irregular outlining of the islet; $\mathbf{C}$. Section from pancreas of group IIb rat (STZ + caffeine $10 \mathrm{mg} / \mathrm{kg}$ ) presenting very similar morphology to the diabetic group IIa; D. Section from rat of group IIc (STZ + caffeine $50 \mathrm{mg} / \mathrm{kg}$ ). Islets show degranulated cytoplasm of most cells, compared with control rat (A); E. Section from pancreas of a group IId rat (STZ + caffeine $100 \mathrm{mg} / \mathrm{kg}$ ) shows the nearly regular outline of an islet with apparently normal appearance of most cells. $H \& E$ staining, scale bar $=50 \mu \mathrm{m}$

cells arranged in irregular, branching, and anastomosing cords separated by blood capillaries (Figure 2A).

In diabetic group IIa, streptozotocin caused severe degenerative changes in the pancreatic islets, mainly at the center of the islets. Karyolysis of the nuclei was visible. Some cells had become enlarged with foamy or clear cytoplasm. Others ballooned and showed completely vacuolated cytoplasm. An apparent reduction in the size and number of islets was noticed, particularly around the larger vessels. Also, the cells in some exocrine acini showed cytoplasmic vacuolation (Figure 2B). Sections from the pancreata of group IIb animals (given $10 \mathrm{mg} / \mathrm{kg}$ caffeine) appeared similar to those of the diabetic group IIa (Figure 2C). Islets from rats of group IIc that received $50 \mathrm{mg} / \mathrm{kg}$ caffeine had degranulated cytoplasm in most cells, as compared with the control sections, and groups of dark nucleated cells could be seen in between (Figure 2D). However, rats from group IId, which received caffeine at a dose of $100 \mathrm{mg} / \mathrm{kg}$, showed islets with nearly regular outlines and almost normal cell morphology (Figure 2E). 

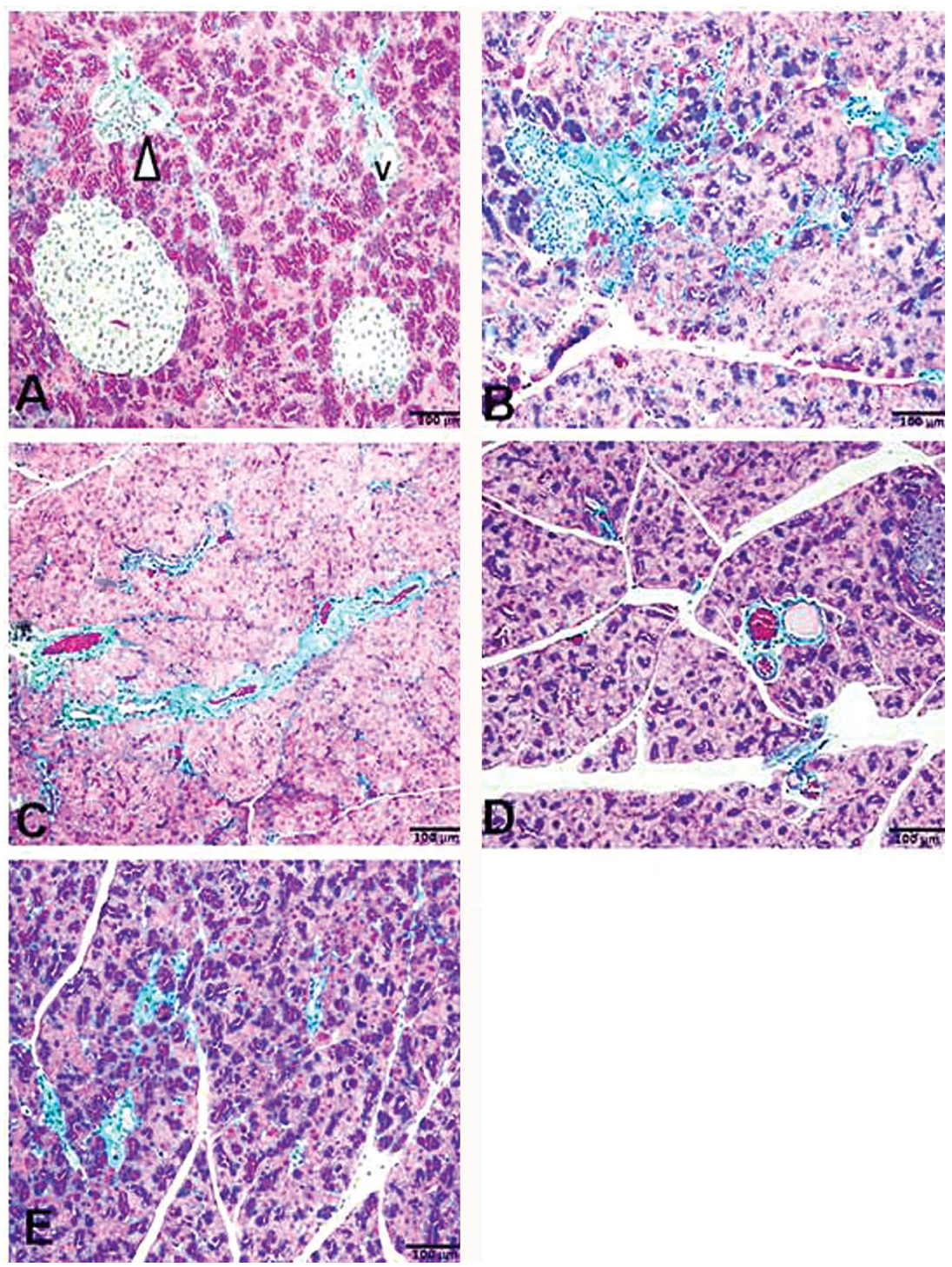

Figure 3. Photomicrographs of sections of the pancreas stained by Masson trichrome. A. Section from control group showing delicate collagen fibers in the capsule, in thin septa and around pancreatic acini. Notice the fibers around the blood vessels (v) and the associated duct system (white triangle); B. Section from pancreas of a diabetic rat (STZ, group IIa) showing the apparent increase in the dense connective tissue stroma in the islets and around some pancreatic ducts and blood vessels; C. Section from pancreas of group IIb rat (STZ + caffeine $10 \mathrm{mg} / \mathrm{kg}$ ) presenting very similar morphology to the diabetic group IIa; D. Section from a rat of group IIc (STZ + caffeine $50 \mathrm{mg} / \mathrm{kg}$ ); E. Section from a pancreas of a group IId rat (STZ + caffeine $100 \mathrm{mg} / \mathrm{kg}$ ) showing diminished connective tissue septa as compared with diabetic group IIa. Masson Trichrome stain, scale bar $=100 \mu \mathrm{m}$

The Masson trichrome staining of the pancreas from the control rats (group I) revealed a normal structure characterized by the presence of delicate collagen fibers in the septa and around the pancreatic acini (Figure 3A). The collagen fibers were seen to incompletely surrounding the islets and around the blood capillaries between the endocrine cells of the islets (Figure 3A). In the diabetic group IIa, the dense connective tissue stroma was observed around some pancreatic ducts and blood vessels. The collagen fibers were seen around the blood capillaries between the endocrine cells of the islets (Figure 3B). Sections from the pancreata of the group IIb rats (caffeine $10 \mathrm{mg} / \mathrm{kg}$ ) appeared similar to those of the diabetic group. Some islets appeared to be completely fibrosed (Figure 3C). In group IIc (caffeine $50 \mathrm{mg} / \mathrm{kg}$ ), the thickening of the connective tissue septa was less frequently seen, compared with the diabetic group (Figure 3D). In group IId (caffeine $100 \mathrm{mg} / \mathrm{kg}$ ), decreases in collagen fibers and fibrous septa were evident in comparison with the other groups of diabetic rats treated with lower doses of caffeine (Figure 3E). 

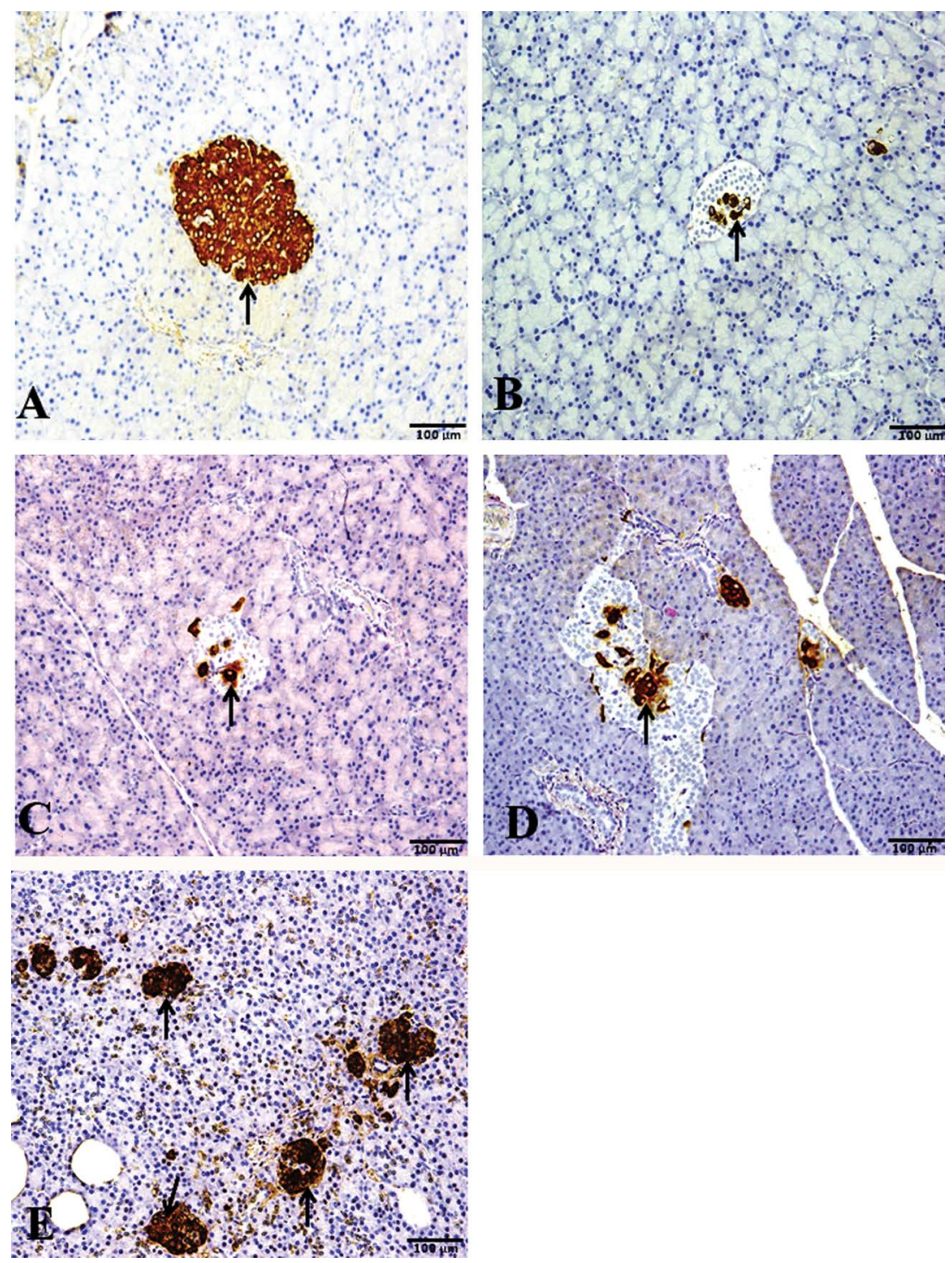

Figure 4. Photomicrographs of insulin immunohistochemical staining of pancreatic islets. A. Section of the pancreas of the control group showing strong immunoreactivity of insulin in beta-cells, which occupy most of the islet. B. Pancreas of a diabetic rat (STZ, group IIa) showing marked reduction in the immunohistochemical expression of insulin in beta-cells (arrow). C. In the pancreas of group IIb rat (STZ + caffeine $10 \mathrm{mg} / \mathrm{kg}$ ), the apparent marked decrease in number and area of beta-cells is evident in comparison with control group (A). D. Section from rat of group IIb (STZ + caffeine 50 $\mathrm{mg} / \mathrm{kg}$ ) presenting an apparent increase in the number (arrow) and area of beta-cells compared with groups IIa and IIb (Figure 4 C\&B). E. Section from pancreas of a group IIc rat (STZ + caffeine $100 \mathrm{mg} / \mathrm{kg}$ ) showing an evident increase in insulin expressing beta-cells with normal density, compared with diabetic group IIa (B). IHC by anti-insulin antibodies, scale bar $=100 \mu \mathrm{m}$

\section{Immunohistochemical evaluation}

In control group I, the insulin secreting cells or betacells represented the major cell population of the islets, occupying mainly the central zone. Positive insulin expression was seen in the form of dark brown granules present in the cytoplasm of beta-cells (Figure 4A). The diabetic group IIa showed a marked reduction in beta-cells number (Figure 4B). Immunostained beta-cells from group IIb appeared to be similar to that of diabetic group IIa (Figure 4C). An apparent increase in the number and percentage area of reactive beta-cells in group IIc (Figure 4D) was observed, as compared with the control diabetic group IIa. Some islets of the group IId rats presented increased beta-cell populations, while others had percentage areas of beta-cells comparable to group IIa (Figure 4D). 

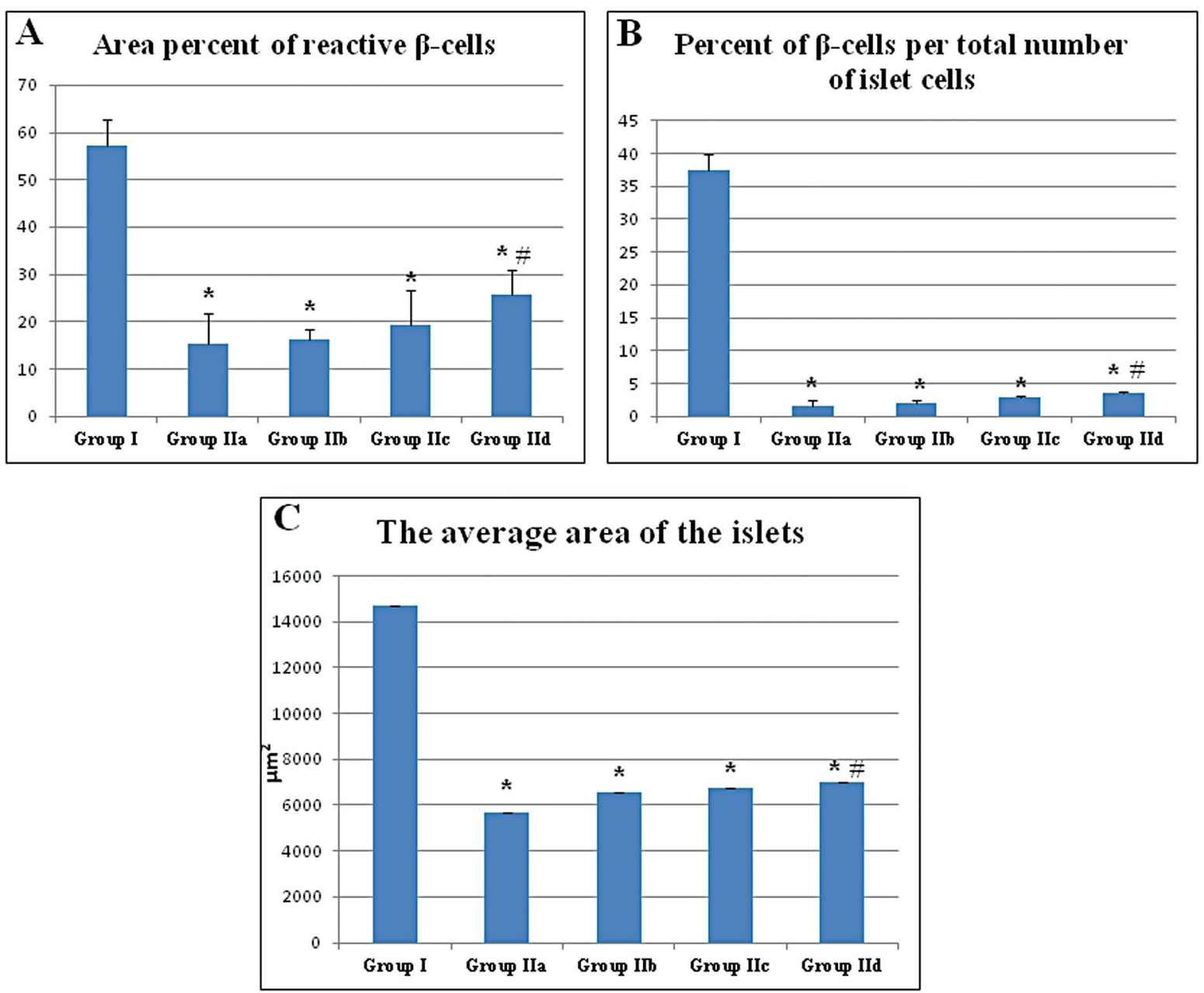

Figure 5. Morphometric measurements showing changes in the mean values of: A. Percentage area of insulin reactive beta-cells (\%); B. Percentage of beta-cells per total number of islet cells (\%); C. Average area of the islets $\left(\mu^{2}\right)$. ${ }^{*}$ Significant compared with Group I (nondiabetic control), P < 0.05, "Significant compared with Group IIa (diabetic), P $<0.05$

\section{Morphometric analysis}

The percentage of beta-cells per total islet cell, the percentage area of reactive beta-cells, and the average area of the islets all significantly decreased in diabetic rats in comparison with control group I, for both the untreated group (IIa) and the group treated with $10 \mathrm{mg} / \mathrm{kg}$ (group IIb) and $50 \mathrm{mg} / \mathrm{kg}$ (group IIc) doses of caffeine. However, group IId $(100 \mathrm{mg} / \mathrm{kg})$ showed a significant increase in all morphometric parameters, as compared with the untreated diabetic group (Figure 5).

\section{Discussion}

Although caffeine has been the subject of many studies aimed at determining its impact on various biochemical and physiological processes, the experi- mental studies dealing with the histological changes to the islets of Langerhans in diabetes are scarce. Diabetes mellitus is a global problem characterized by hyperglycemia and the destruction of the microscopic structure of the beta-cells of the pancreatic islets of Langerhans. Streptozotocin (STZ) has been widely employed to induce type-1 diabetes in animal models. A single injection of streptozotocin $(45-65 \mathrm{mg} / \mathrm{kg}$ intraperitoneally) can be used to induce diabetes in rats $[14,21]$.

In this study, we investigated the effect of caffeine on the microscopic structure of pancreatic Langerhans islets in rats with STZ-induced diabetes. A previous biochemical study produced similar results to the current findings. Kagami et al. stated that different doses of oral caffeine administration $(50-100 \mathrm{mg} / \mathrm{kg}$ per day) for three days recovered the STZ-induced elevation of fasting plasma glucose concentrations and 
pancreatic insulin content. Caffeine was postulated to protect beta-cells against STZ toxicity [14].

The present biochemical results were in accordance with the observations of the previous study, which reported that supplementation of the diet with cocoa powder extract can help to improve insulin resistance due to its flavonoid content, which acts as an antioxidant [22]. Yet other authors have found a lack of significant difference in fasting plasma glucose and insulin levels after 4 weeks of cocoa extract supplementation (which contains $230 \mathrm{mg}$ caffeine per $100 \mathrm{~g}$ ) in obese-diabetic $(\mathrm{Ob}-\mathrm{db})$ rats [23]. However, supplementation of the diet with cocoa powder extract has been suggested to reduce blood glucose concentration in STZ-induced diabetes in rats [24]. Caffeine is known to increase the glucose transport rate in the absence of insulin in rodent skeletal muscles [25, 26]. Also, caffeine activates cyclic AMP-dependent protein kinase through an insulin-independent mechanism, which increases AMP kinase-1 to promote glucose transport. Caffeine antagonizes the adenosine A1 receptors in skeletal muscles, which improves glucose tolerance in rats [27]. These mechanisms may partially explain the reported hypoglycemic effect of caffeine in the present study.

The present biochemical results parallel the histological observations of the endocrine pancreas. The insulin-producing beta-cells were degraded and reduced in number in diabetic rats, resulting in decreased serum insulin concentration. Although low doses of caffeine failed to lead to recovery from the degenerative effects of STZ on the islets of the pancreas, high doses of caffeine $(100 \mathrm{mg} / \mathrm{kg} /$ day $)$ were able to reduce the morphological alterations of the islets of Langerhans in diabetic rats. This beneficial effect could be explained by the action of metabolic products of caffeine, such as theophylline, over a long period. Theophylline is known as smooth-muscle relaxant, and so may have a vasodilator effect on the blood vessels supplying the pancreas.

The immunohistochemical findings and the morphometric measurements presented in our study confirm the results reported by Ahmadi et al., who found a decreased number of insulin immunoreactive cells in the pancreatic islets of diabetic rats, along with a disrupted ultrastructure of beta-cells [28]. The present results show that caffeine at a dose of $100 \mathrm{mg} / \mathrm{kg} \mathrm{BW} /$ day can induce significant improvements in the functioning of beta-cells, as evidenced by the elevated serum insulin level.

The results could be partially explained by considering the mode of action of STZ, which induces an increased release of reactive oxygen species, subsequently causing DNA damage [6]. This damage leads to activation of DNA repair enzyme poly ADP-ribose polymerase-1 (PARP-1). In consequence, a reduction in intracellular NAD is followed by ATP depletion, which leads to pancreatic beta-cell death [6]. Caffeine metabolites may help treat the toxic effects of STZ on beta-cells by inhibiting PARP-1 [29]. Moreover, it has been proposed that caffeine protects pancreatic beta-cells from the damage caused by the free radicals produced by oxidative stress, and prevents membrane disruption $[14,30]$.

In brief, the conclusion of the present study is that the highest applied dose of caffeine may have a protective role on the biochemical and microscopic changes of pancreatic beta-cells in STZ-induced diabetic rats. It is recommended that further studies are carried out in order to more accurately determine the dose of caffeine required and to establish its potential as a new therapeutic and protective tool against diabetes.

\section{References}

1. Minamisawa M, Yoshida S, Takai N. Determination of biologically active substances in roasted coffees using a diode-array HPLC system. Anal Sci. 2004;20:325-328.

2. Fredholm BB, Battig K, Holmen J, Nehlig A, Zvartau EE. Actions of caffeine in the brain with special reference to factors that contribute to its widespread use. Pharmacol Rev. 1999;51:83-133.

3. Pizziol A, Tikhonoff V, Paleari CD et al. Effects of caffeine on glucose tolerance:a placebo controlled study. Eur J Clin Nutr. 1998;52:846-849.

4. Isogawa $\mathrm{A}$, Noda $\mathrm{M}$, Takahashi $\mathrm{Y}$ et al:Coffee consumption and risk of type 2 diabetes mellitus. Lancet. 2003;361:703-704.

5. Akbarzadeh A, Norouzian D, Mehrabi MR et al. Induction of diabetes by streptozotocin in rats. IJCB. 2007;22:60-64.

6. Szkudelski T. The mechanism of alloxan and streptozotocin action in B cells of the rat pancreas. Physiol Res. 2001;50:537546.

7. Takeshita F, Kodama M, Yamamoto H et al. Streptozotocin -induced partial beta cell depletion in nude mice without hyperglycaemia induces pancreatic morphogenesis in transplanted embryonic stem cells. Diabetologia. 2006;49:2948-2958.

8. Ikebukuro K, Adachi Y, Yamada Y, Fujimoto S, Seino Y, Oyaizu H. Treatment of Streptozotocin-induced diabetes mellitus by transplantation of islet cells plus bone Marrow cells via portal vein in rats. Transplantation. 2002;73:512-518.

9. Ito M. New model of progressive non-insulin-dependent diabetes mellitus in mice induced by Streptozotocin. Biol Pharmaceut Bull. 1999;22:988-989.

10. Elias D, Prigozin H, Polak N, Rapoport M, Lohse AW, Cohen IR. Autoimmune diabetes induced by the b-Cell toxin STZ. Diabetes. 1994;43:992-998.

11. Horrigan LA, Kelly JP, Connor TJ. Immunomodulatory effects of caffeine:friend or foe? Pharmacol Ther. 2006;111: 877-892.

12. Montilla PL, Vargas JF, Tunez IF, Munoz De Agueda MC, Valdelvira ME, Cabrera ES. Oxidative stress in diabetic rats induced by streptozotocin:protective effects of melatonin. J Pineal Res. 1998:25:94-100.

13. Park IS, Bendayan M. Endocrine cells in the rat pancreatic and bile duct system:alteration in diabetes. Pancreas. 1994;9:566-573. 
14. Kagami K, Morita H, Onda K, Hirano T, Oka K. Protective effect of caffeine on streptozotocin-induced beta-cell damage in rats. JPP. 2008;60:1161-1165.

15. Brăslasu MC, Brăslasu ED, Brădăłan C et al. Experimental studies regarding the diabetes mellitus induced in white wistar rats. Lucrări Stiintifice Medicină Veterinară. 2007;11:109-116.

16. Kekow J, Ulrichs K, Muller-Ruchholtz W, Wolfgang LG. measurement of rat insulin enzyme-linked immunosorbent assay with increased sensitivity, high accuracy, and greater practicability than established radioimmunoassay. Diabetes. 1988;37:321-326.

17. Bancroft and Gamble. Hematoxlyin and eosin, connective tissue and stain, carbohydrates, Chapters 9-11. In:Theory and practice in histological techniques. $6^{\text {th }}$ ed. 2008:121-186.

18. Weidenheim KM, Hinchey WW, Campell WG Jr. Hyperinsulinemic hypoglycemia in adults with islet-cell hyperplasia and degranulation of exocrine cells of the pancreas. Amer Clin Pathol. 1983;79:14-24.

19. O’Brien TD, Hayden OW, Fletehertf A. Immunohistochemical morphometry of pancreatic endocrine cells in diabetic, normoglycemic glucose intolerant and normal cats. J Comp Path. 1986;96:357-369.

20. Jelodar G, Maleki M. Effect of fenugreek, onion and garlic on blood glucose and histopathology of pancreas of alloxan -induced diabetic rats. Indian J Med Sci. 2005;59:64-69.

21. Aref AB, Ahmed OM, Ali LA, Semmler M. Maternal rat diabetes mellitus deleteriously affects insulin sensitivity and Betacell function in the offspring. J Diabetes Res. 2013;429154.

22. USDA National Nutrient Database for Standard Reference, from http://en.wikipedia.org/wiki/Cocoa_solid 1-2-2013 at 10 GMT. Release 24, 2011.
23. Jalil AM, Ismail A, Pei CP, Hamid M, Kamaruddin SH. Effects of cocoa extract on glucometabolism, oxidative stress, and antioxidant enzymes in obese-diabetic (Ob-db) rats. J Agric Food Chem. 2008;56:7877-7884.

24. Jalil AM, Ismail A, Chong PP,Hamid M, Syed KamaruddinaSH. Effects of cocoa extract containing polyphenols and methylxanthines on biochemical parameters of obese-diabetic rats. J Sci Food Agric. 2009;89:130-137.

25. Jensen TE, Rose AJ, Hellsten Y et al. Caffeine induced $\mathrm{Ca}^{(2+)}$ release increases AMPK dependent glucose uptake in rodent soleus muscle. Am J Physiol Endocrinol Metab. 2007;293:E286-E292.

26. Egawa T, Hamada $\mathrm{T}$, Kameda $\mathrm{N}$ et al. Caffeine acutely activates 5 'adenosine monophosphate-activated protein kinase and increases insulin independent glucose transport in rat skeletal muscles. Metabolism. 2009;58:1609-1617.

27. Egawa T, Hamada T, Ma X et al. Caffeine activates preferentially 1-isoform of 5'AMP-activated protein kinase in rat skeletal muscle. Acta Physiol (Oxf). 2011;201:227-238.

28. Ahmadi S, Karimian SM, Sotoudeh M, Bahadori M, Dehghani GA. Pancreatic islet beta cell protective effect of oral vanadyl sulphate in streptozotocin-induced diabetic rats, an ultrastructure study. Pak J Biol Sci. 2010;13:1135-1140.

29. Geraets L, Moonen HJ, Wouters EF, Bast A, Hageman GJ. Caffeine metabolites are inhibitors of the nuclear enzyme poly (ADP-ribose) polymerase-1 at physiological concentrations. Biochem Pharmacol. 2006;72:902-910.

30. Yoshida Y, Hayakawa M, Niki E. Evaluation of the antioxidant effects of coffee and its components using the biomarkers hydroxyoctadecadienoic acid and isoprostane. J Oleo Sci. 2008;12:691-697. 